\title{
CORRIGENDUM
}

\section{Sustaining coastal urban ecosystems}

Torbjörn E. Törnqvist and Douglas J. Meffert

Nature Geoscience 1, 805-807 (2008); published online: 30 November 2008; corrected after print: 30 November 2008.

In this Commentary, in the section 'Sustainable (re)building', second paragraph, the figure for the population density in New Orleans immediately before the exodus caused by Hurricane Katrina was incorrect, it should have read 'only about 2,500'. This has been corrected in the HTML and PDF versions. 